\title{
Effects of Surfactants on Acceleration of Propanil Action
}

\author{
Hiroto NAKAYAMA*, Makoto KONNAI*, Nobumasa ICHIZEN*, \\ Satoru OHBUCHI** and Tetsuo TAKEMATSU* \\ * Weed Control Research Institute, Faculty of Agriculture, Utsunomiya University, \\ 350 Mine-machi, Utsunomiya 321, Japan \\ ** Technical Research Laboratory, Toho Chemical Industries Co. Ltd., 5-2931, \\ Urago-cho, Yokosuka 237, Japan
}

\section{Introduction}

Due to the low water solubilities of herbicidal compounds, surfactants are important components in herbicide formulations, and are used for improving formulative properties. In addition, it has been well recognized that surfactants often enhance and accelerate the action of foliar applied herbicides by improving leaf wettability and cuticle penetration.

SMITH et al. ${ }^{14)}$ reported that the great effectiveness of homologous groups of the POE (polyoxyethylene) alkylphenyl ether type of nonionic surfactants on paraquat, dalapon and amitrole was associated with certain EO (ethylene oxide) mole numbers of the surfactants. NAKAYAMA et al. ${ }^{11)}$ showed that the effects of the POE nonylphenyl ether surfactants on asulam and bialaphos were higher when HLB (hydrophile lipophile balance) values of the surfactants were around 12 and 12-14, respectively. However, the reason that surfactants with certain HLB values or $\mathrm{EO}$ mole numbers are more effective than others in enhancing herbicidal activity is not understood.

Although many attempts have been made to correlate the physicochemical characteristics of surfactants, including HLB value and EO mole number, with observed adjuvant effects, no clear relationships were obtained except for the study with maleic hydrazide $(\mathrm{MH})$ in which adjuvant activity was found to be closely related to the moisture absorption capacity of the surfactants ${ }^{12)}$. WYRILL and BURNSIDE ${ }^{16)}$ could not find any correlation between contact angles of spray solution on plant leaf and adjuvant effect on glyphosate activity. Accordingly, it was suggested that the complex and subtle interaction may be involved in the effect of the adjuvants and that the interaction may not depend merely on the physical characteristics of the spray solution ${ }^{6,13,14)}$. In view of the importance of surfactants for their adjuvant effects, a better understanding of such interaction is needed.

In the case of foliar applied type of herbicides, droplets of spray solution should deposit on the leaf surface and then penetrate the cuticle. Thus, the amount of the deposit and the rate of penetration would play a major role in the efficiency of the applied herbicides. The former seems to be expressed as a function of the contact angle of the spray solution on the plant leaf, and this parameter would be correlated with the spreading of the surfactant solution on a waterproof material such as paraffin wax ${ }^{3,7)}$ and plastic board, since the leaf surface is generally waxy and water-repellent. How-

* A part of this work was reported at the 26th annual meeting of the Weed Science Society of Japan in April, 1987. 
ever, as is shown in many microscopic figures, the leaf surface is not smooth and thus the deposit on it should permeate to rather hydrophobic regions for optimum covering of the surface. In this sense, the texture of the leaf surface seems very similar to that of, for example felt cloth, to which water cannot permeate easily. Furthermore, this permeation process might play an important role in the subsequent penetration which would also be dependent on the physical properties of both surfactants and herbicide and the interaction between them.

Based on this idea, effects of surfactants on the action of the foliar applied type herbicide propanil, especially on the acceleration of its herbicidal action, were evaluated in relation to these two properties of surfactant solutions, i.e., spreading and permeating. Propanil was used in this study as it primarily interferes with photosynthesis ${ }^{2)}$ and thus the efficiency of a spray seems to depend largely on its retention on the leaf surface and its penetration into the cuticle. When propanil is applied in a rather large spray volume to wet the plants uniformly, the amount of deposit does not greatly vary, and thus the difference in the penetration rate would be a major factor affecting the herbicidal activity of the chemical. However, in the case of foliar applied type herbicide which has a mode of action other than inhibition of photosynthesis, possible differences of translocation and/or detoxification of the herbicide in plants should be taken into account to evaluate the effects of surfactants added to the spray solution.

From viewpoints such as these, the accelerating effects of three representative surfactants which differ in their ionic characters on the inhibition of photosynthesis by foliarapplied propanil were directly examined by monitoring $\mathrm{CO}_{2}$ uptake by the treated plants in vivo.

\section{Materials and Methods}

\section{Surfactants and herbicides}

Surfactants employed in this study are listed in Table 1 with their structures and ionic characters. Technical product of propanil (3', 4'-dichloropropionanilide, purity $97 \%$ ) was dissolved in $90 \%$ aqueous acetone for stock solutions. Each spray solution was prepared by dilution after evaporating the

Table 1. List of surfactants

\begin{tabular}{|c|c|c|c|}
\hline No. & Chemical description & $\begin{array}{l}\text { Ionic } \\
\text { form }^{\text {a) }}\end{array}$ & $\begin{array}{l}\text { HLB } \\
\text { value }\end{array}$ \\
\hline 1 & POE (4) nonylphenyl ether & $\mathrm{N}$ & 8.9 \\
\hline 2 & POE (6) nonylphenyl ether & $\mathrm{N}$ & 10.9 \\
\hline 3 & POE (8) nonylphenyl ether & $\mathrm{N}$ & 12.3 \\
\hline 4 & POE (10) nonylphenyl ether & $\mathrm{N}$ & 13.3 \\
\hline 5 & POE (12) nonylphenyl ether & $\mathrm{N}$ & 14.1 \\
\hline 6 & POE (14) nonylphenyl ether & $\mathrm{N}$ & 14.7 \\
\hline 7 & POE (16) nonylphenyl ether & $\mathrm{N}$ & 15.2 \\
\hline 8 & POE (18) nonylphenyl ether & $\mathrm{N}$ & 15.7 \\
\hline 9 & POE (20) nonylphenyl ether & $\mathrm{N}$ & 16.0 \\
\hline 10 & POE (40) nonylphenyl ether & $\mathrm{N}$ & 17.8 \\
\hline 11 & Sodium dioctylsulfosuccinate & A & \\
\hline 12 & $\begin{array}{l}\text { Lauryl-dimethylbenzylammoni- } \\
\text { um chloride }\end{array}$ & $\mathrm{C}$ & \\
\hline 13 & $\begin{array}{l}\text { Stearyl-trimethylammonium } \\
\text { chloride }\end{array}$ & $\mathrm{C}$ & \\
\hline 14 & $\begin{array}{l}\text { Distearyl-dimethylammonium } \\
\text { chloride }\end{array}$ & $\mathrm{C}$ & \\
\hline 15 & $\begin{array}{l}\text { Palmityl-trimethylammonium } \\
\text { chloride }\end{array}$ & $\mathrm{C}$ & \\
\hline 16 & $\begin{array}{l}\text { Stearyl-trimethylammonium } \\
\text { chloride }\end{array}$ & $\mathrm{C}$ & \\
\hline 17 & Aminoacid type & $Z$ & \\
\hline 18 & $\begin{array}{l}\text { Betaine type } \\
\text { (imidazoline derivatives) }\end{array}$ & $Z$ & \\
\hline 19 & Lauryl-dimethylamine oxide & $\mathrm{N}$ & \\
\hline 20 & $\begin{array}{l}\text { The bock polymer of ethylene } \\
\text { oxide and propylene oxide }\end{array}$ & $\mathrm{N}$ & 7.9 \\
\hline 21 & POE (4) nonylphenyl phosphate & A & \\
\hline 22 & $\begin{array}{l}\text { POE polyoxypropylene ether } \\
\text { sulfate }\end{array}$ & A & \\
\hline 23 & POE (2) coco amide & $\mathrm{N}$ & \\
\hline 24 & POE (15) tallow amine & $\mathrm{N}$ & \\
\hline 25 & POE (3) tallow diaminopropane & $\mathrm{N}$ & \\
\hline 26 & $\begin{array}{l}\text { Polymerized sodium salts (2) of } \\
\text { naphthalenesulfonic acids }\end{array}$ & A & \\
\hline 27 & $\begin{array}{l}\text { Polymerized sodium salts (9) of } \\
\text { naphthalenesulfonic acids }\end{array}$ & $\mathrm{A}$ & \\
\hline
\end{tabular}

POE : polyoxyethylene

a) $\mathrm{A}=$ anionic $; \mathrm{C}=$ cationic $; \mathrm{N}=$ nonionic ; $\mathrm{Z}=\mathrm{zwit}$ ter ionic. 
acetone.

\section{Spreading and permeating properties of surfactant solutions}

Spreading and permeating properties of surfactant solutions $(0.1 \% \mathrm{w} / \mathrm{v})$ were measured at $28^{\circ} \mathrm{C}$ under laboratory conditions. The spreading was measured on a plastic board by dropping $20 \mu 1$ of the surfactant solutions by a microsyringe onto the plastic board and measuring the diameter of the droplet with slide calipers.

Permeation of a surfactant solution was determined by the felt disk method ${ }^{15)}$ : one inch $i . d$. felt disks were carefully floated on a solution and the time required for the solution to penetrate the felt disk was measured by stopwatch for a maximum of 180 seconds. Under these conditions, pure water did not penetrate the disk at all. Each measurement was replicated 5 times.

\section{Phytotoxicity of surfactants}

In individual ceramic pots $(i . d .9 \mathrm{~cm}$ ), sixteen uniform plants of barnyard millet (Echinochloa crus-galli L.) at the 2 leaf stage, $7.5-9 \mathrm{~cm}$ high, grown in a glasshouse were sprayed with $1 \mathrm{ml}$ of a $0.1 \%$ surfactant solutions (this spray volume corresponds to $150 l / 10 \mathrm{a}$ ) by a hand sprayer (caliber : $0.8 \mathrm{~mm}$ ) attached to an air-pump (flow rate:15 l/min).

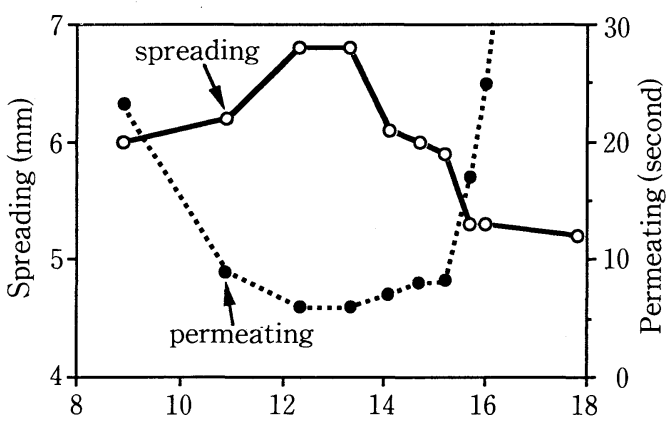

$\mathrm{H}$ L B

Fig. 1. Spreading and permeating properties of POE nonylphenyl ether surfactant solutions $(0.1 \%)$.

Spreading : spreading on a plastic board (mm)

Permeating: time required to penetrate a felt disk (seconds)
Phytotoxicity was evaluated by weighing the above-ground portions of the plants 5 days after treatment. Each treatment was replicated 5 times.

\section{Effects of surfactant on herbicidal activity of propanil}

In individual $9 \mathrm{~cm}$ i.d. ceramic pots, sixteen uniform plants of barnyard millet at the 2 leaf stage grown in a similar manner as described above were sprayed. Each spray solution contained an amount of propanil calculated to correspond to $150 \mathrm{~g}$ a.i. $/ 10 \mathrm{a}$ and $0.1 \%$ of a surfactant. Spray volume was $1 \mathrm{ml}$ (150 l/10 a) and each treatment was replicated 5 times.

Herbicidal activity was determined by weighing the aboveground portions of the plants 5 days after treatment (Table 2). In some experiments the activity was visually evaluated during the 9 days following treatment and was expressed by a zero to 5 rating system in which zero and 5 indicate no effect and complete killing, respectively (Fig. 2).

5. Effects of surfactants on inhibition of photosynthesis by propanil

In individual $9 \mathrm{~cm}$ i.d. ceramic pots, sixteen uniform plants of barnyard millet at the 2 leaf-stage grown in a similar manner as described above were sprayed with a $50 \mathrm{ppm}$ propanil solution containing $0.1 \%$ of the surfactant 4,11 or 12 (Table 1), or no sur-

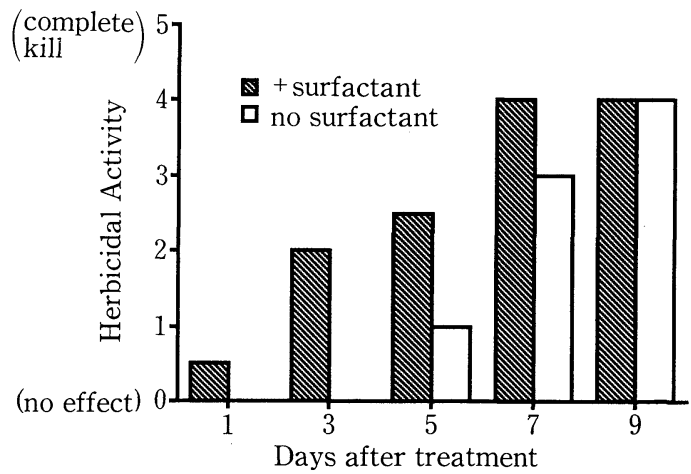

Fig. 2. Herbicidal activity of propanil $(150 \mathrm{~g} / 10$ a) applied with POE (8) nonylphenyl ether surfactant $(0.1 \%)$ against barnyard millet. 
factant, respectively. Treated pots were placed in a Shimadzu SPB-03 growth chamber $\left(65 \mathrm{klux}, 25^{\circ} \mathrm{C}\right.$, flow rate of air, $\left.10 \mathrm{l} / \mathrm{min}\right)$ and the $\mathrm{CO}_{2}$ uptake by the plants was monitored by a Shimadzu IRA-102 spectrometer. The results were expressed as the $\mathrm{CO}_{2}$ assimilation (percent): $\left(\mathrm{CO}_{2}\right.$ uptake rate after treatment/ $\mathrm{CO}_{2}$ uptake rate before treatment) $\times 100$. Each treatment was replicated 3 times.

\section{Results and Discussion}

\section{Spreading and permeating properties}

Although the physical properties of surfactant solutions including the two parameters discussed here are known to vary with the concentration of surfactant ${ }^{4,5)}$, all surfactant solutions were employed at a concentration of $0.1 \%$ in this study. This concentration was chosen as normal concentrations of surfactants in spray solutions are in the range $0.1 \sim 0.5 \%$, and, in addition, at higher concentrations, it may be difficult to examine adjuvant effects due to the possibly phytotoxic character of the surfactants themselves.

The spreading and permeating properties of the surfactant solutions $(0.1 \%)$ are summarized in Table 2. Spreading property varied from 4.4 to $9.7 \mathrm{~mm}$. Among the surfactants tested, the sodium dioctyl sulfosuccinate surfactant (11) showed the highest spreading property $(9.7 \mathrm{~mm})$ and the POE coco amine (23) was the second highest $(7.1 \mathrm{~mm})$.

The permeating property varied in a larger range than that of the spreading property and most of the POE nonylphenyl ether type surfactants $(2 \sim 7)$ showed higher permeabilities.

The $0.1 \%$ solutions of the homologous group of POE nonylphenyl ether nonionic surfactants $(1 \sim 10)$ varied in their spreading and permeating properties in proportion to their HLB values as shown in Fig. 1. In these surfactants, the maximum spreading property was in the range $12 \sim 13$ of the HLB values of the surfactants. The permeating property was higher in the range around 11 $\sim 15$, especially $12 \sim 13$ of the HLB values, and was in good agreement with the results reported by SUZUKI et al. ${ }^{15)}$. It should be noted that these properties run parallel to each other in proportion to their HLB values. A similar trend was also found when these properties were plotted against the $\mathrm{EO}$ mole numbers, because the HLB value varies in proportion to EO mole number within the homologues of the surfactants. These results indicate that the spreading and permeating

Table 2. Physical properties of surfactant solutions and their effects on propanil activity.

\begin{tabular}{|c|c|c|c|}
\hline $\begin{array}{l}\text { Surfactant } \\
\text { no. }\end{array}$ & $\begin{array}{l}\mathrm{SP} \\
(\mathrm{mm})\end{array}$ & $\begin{array}{c}\mathrm{PP} \\
\text { (second) }\end{array}$ & $\begin{array}{c}\text { Herbicidal } \\
\text { activity (\% inhibition) }\end{array}$ \\
\hline 1 & 6.0 & 23 & 43 \\
\hline 2 & 6.2 & 9 & 48 \\
\hline 3 & 6.8 & 6 & 59 \\
\hline 4 & 6.8 & 6 & 55 \\
\hline 5 & 6.1 & 7 & 52 \\
\hline 6 & 6.0 & 8 & 45 \\
\hline 7 & 5.9 & 8 & 44 \\
\hline 8 & 5.3 & 17 & 43 \\
\hline 9 & 5.3 & 25 & 42 \\
\hline 10 & 5.2 & $>180$ & 42 \\
\hline 11 & 9.7 & 30 & 46 \\
\hline 12 & 4.9 & $>180$ & 35 \\
\hline 13 & 5.3 & $>180$ & 36 \\
\hline 14 & 4.5 & $>180$ & 45 \\
\hline 15 & 5.7 & $>180$ & 40 \\
\hline 16 & 5.3 & $>180$ & 38 \\
\hline 17 & 5.5 & 39 & 33 \\
\hline 18 & 5.0 & 48 & 35 \\
\hline 19 & 5.6 & $>180$ & 40 \\
\hline 20 & 5.5 & $>180$ & 46 \\
\hline 21 & 5.0 & 31 & 43 \\
\hline 22 & 5.1 & $>180$ & 47 \\
\hline 23 & 7.1 & 35 & 45 \\
\hline 24 & 5.4 & $>180$ & 45 \\
\hline 25 & 5.2 & $>180$ & 39 \\
\hline 26 & 4.4 & 44 & 38 \\
\hline 27 & 4.6 & $>180$ & 37 \\
\hline control $^{* *}$ & 4.4 & $>180$ & 29 \\
\hline
\end{tabular}

SP : spreading property

PP : permeating property (a maximum of $180 \mathrm{sec}$ onds)

$\%$ inhibition* : \% inhibition of fresh weight control $^{* *}$ : water 
properties are closely related not only to each other but also to both HLB values and EO mole numbers in these homologous surfactants.

However, this same correlation between the two properties could rarely be found with other surfactants tested; some of them may show optimal spreading and permeating at lower or, possibly, at higher concentrations than $0.1 \%$.

\section{Phytotoxicity of surfactants}

None of the $0.1 \%$ surfactant solutions themselves had phytotoxicity against barnyard millet (data not shown). Therefore, any changes in the herbicidal efficiency brought about by an addition of the surfactants at the concentration used should be regarded as adjuvant activity.

\section{Effect of surfactants on herbicidal activity of propanil}

Enhancement of propanil activity by the use of surfactants has been reported ${ }^{8)}$, and in this study we primarily examined the effects of the surfactants on the acceleration of the propanil action, i.e., how quickly the herbicidal symptoms appeared when a surfactant was added. Propanil was applied at a dosage of $150 \mathrm{~g} / 10$ a which was below the lethal dosage for barnyard millet under the experimental conditions, and was applied in a spray volume $(150 l / 10$ a) to wet the test plants uniformly. Figure 2 shows the effects of the POE nonylphenyl ether surfactant (3, $\mathrm{EO}=8$ moles) on propanil activity. Clearly, the propanil action was accelerated by the addition of the surfactant to the spray solution. In the plots where propanil had been applied with the surfactant, the herbicidal symptoms became obvious the day following treatment. In contrast, in plots where propanil was applied without surfactant, the symptoms did not appear until 5 days after treatment. However, if the herbicidal activity was evaluated 9 days after treatment, surfactant effect on the activity was not significant; there was no difference in the activity between the two plots. Therefore, the effects of the surfactant were examined by evaluating the herbicidal activity 5 days after treatment and the data are summarized in Table 2.

Acceleration effect of the POE nonylphenyl ether surfactants $(1 \sim 10)$ on the propanil action was higher with the HLB range of 11 $\sim 14$ (Fig. 3 and Table 2). SMITH et al. ${ }^{14)}$ and NAKAYAMA et al. ${ }^{11)}$ reported that the herbicidal activities of several chemicals were enhanced by the addition of the surfactants with those HLB values.

Although the sodium dioctyl sulfosuccinate anionic surfactant (11) showed an excellent spreading property, it was less effective in accelerating propanil action than those of the POE nonylphenyl ether surfactants (2 5), presumably due to its lower permeating property ; under the experimental conditions, leaf wettability would not be a major factor affecting the activity as greater spray volume was used in this study.

As mentioned, within a series of homologous surfactants like the nonylphenyl ether surfactants, the spreading and permeating properties were correlated with each other and they varied in proportion to the HLB values or EO moles for maximum effect. However, this was not true with other surfactants, and it seems almost impossible to find a general rule applicable to all types.

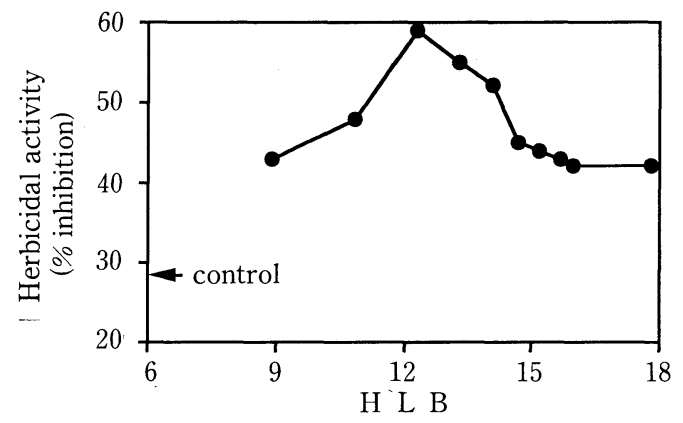

Fig. 3. Herbicidal activity of propanil $(150 \mathrm{~g} / 10$ a) applied with POE nonylphenyl ether surfactants $(0.1 \%)$ against barnyard millet. 
In fact, with all the surfactants tested, analysis of the relationship between the spreading or permeating property of a surfactant solution and the acceleration of propanil action evaluated 5 days after treatment gave respective correlation coefficients of $0.49(\mathrm{p}<0.1)$ and -0.57 (logarithmic, $\mathrm{p}<0.1$ ). However, a better correlation coefficient 0.77 ( $\mathrm{p}<0.1$ ) was obtained between the acceleration-activity and the values calculated as follows: values of spreading property $\times(1 /$ values of permeating property), indicating that the surfactants which were good in both properties showed higher acceleration-activity; in this equation, a maximum of 180 (sec.) for the permeation property was applied for all surfactants tested.

Retention of droplets on the leaf surface can be measured by spraying a dye solution, and KADOTA and MATSUNAKA reported that surfactant solutions with lower surface tension (ST) showed higher retention ${ }^{7)}$. Since ST and the contact angle had a highly positive correlation in their study, and, further, the contact angle is directly related to the spreading property, retention would be a

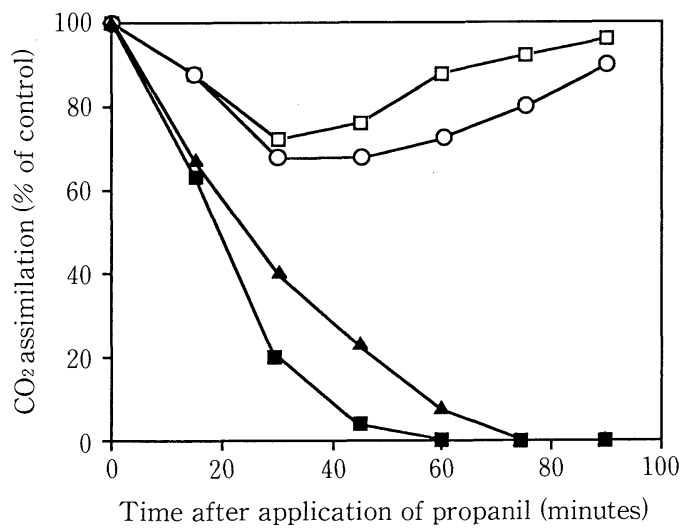

Fig. 4. Inhibition of photosynthesis by propanil $(50 \mathrm{ppm})$ applied with the surfactants $(0.1 \%)$.

$\square$ : without surfactant

口 : with POE (10) nonylphenyl ether (No.4)

$\Delta$ : with sodium dioctyl sulfosuccinate (No. 11)

$\bigcirc$ : with lauryl dimethylbenzylammonium chloride (No.12) function of the spreading property. Retention on the leaf surface would not always correlate to the adjuvant effect, however, since the subsequent process including the penetration of the applied chemical through the cuticle may be more important in some cases.

\section{Effects of surfactants on inhibition of photosynthesis by propanil}

When propanil reaches its site of action, chloroplasts, it interferes with photosynthesis, and thus the rate of uptake or penetration of the herbicide through the cuticle could be estimated by measuring the photosynthetic activity of the treated plants. Photosynthetic activity in vivo can be monitored by several methods, e.g. measuring $\mathrm{CO}_{2}$ uptake ${ }^{10)}$ or leaf fluorescence ${ }^{1)}$.

Figure 4 depicts the changes in photosynthetic activity of propanil-treated plants by monitoring $\mathrm{CO}_{2}$ uptake (assimilation). The surfactants used in this experiment were three representatives of different ionic characters: POE (10) nonylphenyl ether (4, nonionic), sodium dioctyl sulfosuccinate (11, anionic) and lauryl dimethylbenzyl ammonium chloride (12, cationic). A sublethal dose of propanil, $50 \mathrm{ppm}$, was applied in this experiment so that the effects of the surfactants on propanil action became clearer. In a preliminary experiment, it was confirmed that solutions of the three surfactants $(0.1 \%)$ themselves showed no effect on $\mathrm{CO}_{2}$ uptake by the plants (data not shown). Propanil applied without surfactant or with the No. 12 surfactant $(0.1 \%)$ showed slight inhibition of $\mathrm{CO}_{2}$ uptake although the treated plants recovered from the inhibition within $90 \mathrm{~min}$. In contrast, propanil applied with the No. 4 or the No. 11 surfactant showed strong inhibition, completely inhibiting $\mathrm{CO}_{2}$ uptake $60 \sim 75 \mathrm{~min}$. after treatment, and in this case the treated plants did not recover within $90 \mathrm{~min}$. These results indicate that the No. 4 and the No. 11 surfactants $(0.1 \%)$ enhanced and accelerated the propanil action presumably by improving the penetration of the chemical. In addition, 
the effects of the three surfactants $(4,11$ and 12) were in good agreement with those in the pot test as described earlier (Table 2).

The permeating and spreading properties of the surfactant solutions have been discussed in relation to their effects on the acceleration of propanil action, and these properties may help in predicting surfactant adjuvant effect. In addition, some of the surfactants were found to accelerate the propanil action by improving the cuticle penetration. However, we did not try to evaluate the adjuvant activity of the surfactants at different concentrations, and thus some may be more effective at other optimal concentrations.

\section{Summary}

Effects of various types of surfactants on the action of the foliar applied type herbicide propanil, especially on the acceleration of its herbicidal action, were evaluated in relation to the physical properties, spreading and permeating properties of the surfactant solutions $(0.1 \%)$.

The $0.1 \%$ solutions of the POE nonylphenyl ether surfactants varied in their spreading and permeating properties in proportion to their HLB values, with the maximum being around $12 \sim 13$ of the HLB value.

Most of the surfactants added accelerated the propanil action applied at a sub-lethal dosage against barnyard millet (Echinochloa crus-galli L.). The effects on this action were higher at about 12 of HLB or 8 of EO moles in the POE nonylphenyl ether surfactants. In addition, with all the surfactants tested, a better correlation coefficient $0.77(\mathrm{p}<0.1)$ was obtained between the accelerationactivity and the values calculated as follows: values of spreading property $\times(1 /$ values of permeating property), indicating that the surfactants which were good in both properties showed higher acceleration-activity.

Effects of three surfactants with different ionic characters on the propanil action were also examined by monitoring the photosynthetic activity of the treated plants. The data showed a similar trend to those in the pot test and the No. 4 surfactant was the most effective, indicating that it accelerated propanil action presumably by improving cuticle penetration of the herbicide.

\section{References}

1) Butler, W.L. : Fluorescence yield in photosynthetic systems and its relation to electron transport. In "Current Topics in Bioenergetics", D.R. SANDI, ed., Academic Press, New York and London, Vol. 1 pp. 49 -73 (1966).

2) FedtKe, C. : C. Photosynthesis. In "Biochemistry and Physiology of Herbicide Action" Springer-Verlag, Berlin, Heidelberg, New York, pp. 19-113 (1982).

3) FoY, C.L. and L.W. SMITH (1965) : Surface tension lowering, wettability of paraffin and corn leaf surfaces, and herbicidal enhancement of dalapon by seven surfactants. Weeds, 13, 15-19.

4) Fujimoto, T. : Shin-kaimenkasseizainyumon, Sanyo Chemical Industries Co. Ltd., pp. 12-24 (1985) (in Japanese).

5) Hull, H.M., D.G. DAvis and G.E. Stolzen. BERG : Action of adjuvants on plant surfaces. In "Adjuvants for Herbicides", Weed Science Society of America, pp. 26-67 (1982).

6) JANSEN, L.L. (1964) : Relation of structure of ethylene oxide ether-type nonionic surfactants to herbicidal activity of watersoluble herbicides. J. Agric. Food Chem., 12, 223-227.

7) Kadota, G. and S. Matsunaka (1986): Effect of surfactants on foliar wettability in rice plants. J. Pestic. Sci., 11, 597-603.

8) KONNAI, M., N. ICHIZEN and Y. TAKAHASHI (1967) : Synergistic action of cyclohexenylcyclohexanone on the herbicidal activity of propanil. Weed Res., Japan, 6, 74-79 (in Japanese with English summary).

9) MC WhorTer, C.G. : The use of adjuvants. In "Adjuvants for Herbicides", Weed Science Society of America, pp. 10-25 (1982).

10) NAKAmURA, H. (1967): Effect of a sur- 
factant on the herbicidal activity of $s$ triazine herbicides in foliar sprays. Weed Res., Japan, 6, 48-50 (in Japanese with English summary).

11) NAKAYAMA, H., M. KONNAI and N. ICHIZEN (1988) : Studies on joint action of herbicides with surfactants. J. Japanese Society of Turfgrass Science, 17, 49-52 (in Japanese with English summary).

12) OTsuji, K. (1986) : Effects of surfactants on foliar-absorption of maleic hydrazide. J. Pestic. Sci., 11, 387-392 (in Japanese with English summary).

13) PARR, J.F. and A.G. Norman (1965) : Considerations in the use of surfactants in plant system. Bot. Gaz., 126, 86-96.
14) SMith, L.W., C.L. FOY and D.E. BAYER (1966) : Structure-activity relationships of alkyl phenol ethylene oxide ether non-ionic surfactants and three water soluble herbicides. Weed Res., 6, 233-242.

15) Suzuki, Y., H. Tsutsumi and K. ShINOdA (1985) : Wetting phenomena of felt by surfactant solutions and relation to hydrophilelipophile balance. Yukagaku, 34, 277-282 (in Japanese with English summary).

16) WYRILL, J.B. III and O.C. BURNSIDE (1977) : Glyphosate toxicity to common milkweed and hemp dogbane as influenced by surfactants. Weed Sci., 25, 275-287.

(Received November 1, 1988)

\title{
プロパニルの殺草活性に及ぼす界面活性剤の影響 \\ 中山裕人* · 近内誠登* - 一前宣正* ・ 大㴊 悟** ・ 竹松哲夫* \\ *宇都宮大学, **東邦化学工業
}

\begin{abstract}
摘 要
プロパニルの除草活性発現に及ぼす界面活性剤 (Table 1)の速効性賦与効果を, 界面活性剤水溶液 $(0.1 \%)$ のプラスチック板上での拡がり（拡展性）とフェルト沈降法によるフェルト地への浸透性（湿潤性）の二つ の物性パラメーターとの関連から検討した（Table 2)。

POEノニルフェニルエーテルタイプの界面活性剤水溶液の物性はHLB 值により変動し, 拡展性は HLB12 13で，浸透性は HLB11〜15で優れていた（Fig. 1)。即ち，両物性の間には相関関係が認められた。 しかし，その他の界面活性剤では，明確な関連性は認められなかった。

温室内ポット試験では葉面の濡れを均一にするために $150 \quad l / 10 \mathrm{a}$ の散布水量とした。界面活性剤の添加に よりプロパニルの食用ビエ (Echinochloa crus-galli L.) に対する殺草効果に速効性が付与され, 両物性とも に比較的優れていた POEノニルフェニルエーテルタイプ（HLB 值12１3）のものが優れた効果を示した

(Figs. 2, 3, Table 2)。そこで, それぞれの物性と速効性賦与効果の関連性を検討したところ, 拡展性およ び湿潤性の值と速効性賦与効果との間の相関係数はそれぞれ $\mathrm{r}=0.49, \quad \mathrm{r}=-0.57$ (いずれも危険率 $1 \%$ 以 下で有意）であったが, 更に両物性值の組合せについて検討した結果, 速効性賦与効果と, 〔拡展性の值】 $\times$ 〔 1 /湿潤性の值〕の式から得られた值の間では $\mathrm{r}=0.77$ (危険率 $1 \%$ 以下で有意）という比較的高い相関 係数が得られた。このことから，拡展性，湿潤性の両物性に優れた界面活性剤はプロパニルに対する速効性 賦与効果が高い傾向にあることが示された。

また, 炭酸ガス吸収速度を指標に, プロパニル処理後の光合成能を経時的に検定した結果, ポット試験で 効果の高かった界面活性剤の添加により，プロパニルの光合成阻害活性が増強され，かつ速効的に発現する ことが分かった。このことは，これらの界面活性剤はプロパニルの表皮層への浸透性を高めているものと考 えられる (Fig. 4)。
\end{abstract}

